Al-Uqud: Journal of Islamic Economics E-ISSN 2548-3544, P-ISSN 2549-0850 Accredited No. 28/E/KPT/2019
Volume 4 Issue 1, January 2020

DOI:10.26740/al-uqud.v4n1.p69-82

Page 69-82

\title{
Productivity Comparation of Islamic and Conventional Banks in Indonesia
}

\author{
Marhanum Che Mohd Salleh ${ }^{1}$, Lina Nugraha Rani ${ }^{2 *}$ \\ ${ }^{1}$ Department of Finance, Kulliyyah of Economics and Management Sciences, International \\ Islamic University Malaysia. Jalan Gombak, 53100 Kuala Lumpur, Malaysia \\ ${ }^{2}$ Department of Islamic Economics, Faculty of Economics and Business, Universitas \\ Airlangga. Jalan Airlangga 4, Surabaya 60286, Indonesia
}

\begin{abstract}
This study aimed to compare the productivity performance of Islamic and Conventional Banks in Indonesia with the Total Factor Productivity Index (TFPCH) indicator. The sample of this study was 14 banks consisting of 7 Islamic Banks and 7 Conventional Banks from 2011-2018. Secondary data were obtained from the annual financial statements of each sample. To measure the total factor productivity index (TFPCH), the Malmquist Productivity Index (MPI) was used as a measure of productivity. It found that the productivity of Conventional Banks was slightly superior compared to Islamic Banks, with contributions from Technical / Technological Change (TECHCH) being the most influential component in the TFPCH composition. Further, there was an indication of a technical increase in both types of banks during the period. The results of this study implied banking industry players to increase their efficiency particularly the usage of technology in providing efficient services to users.
\end{abstract}

Keywords: Performance; Total factor productivity index; Malmquist productivity index; Islamic banks and conventional banks.

Paper type: Research paper

*Corresponding author: linanugraha@ feb.unair.ac.id

Received: August 15, 2019; Accepted: January 14, 2020; Published: January 20, 2020

Cite this document: Mohd Salleh, M. C. \& Rani, L. N. (2020). Productivity Comparation of Islamic and Conventional Banks in Indonesia. Al-Uqud: Journal of Islamic Economics, 4(1), 69-82. doi: http://dx.doi.org/10.26740/al-uqud.v4n1.p69-82

Copyright $@$ ( 2020, Al-Uqud: Journal of Islamic Economics http://journal.unesa.ac.id/index.php/jie 


\begin{abstract}
Abstrak: Tujuan penelitian ini adalah untuk mengetahui perbandingan kinerja produktivitas Bank Umum Syariah dan Bank Umum Konvensional di Indonesia dengan indikator Total Factor Productivity Index (TFPCH). Sampel penelitian sebanyak 14 Bank yang terdiri dari 7 Bank Umum Syariah dan 7 Bank Umum Konvensional dengan rentang periode 2011-2018. Data sekunder diperoleh dari laporan keuangan tahunan masingmasing sampel. Untuk mengukur total factor productivity index (TFPCH) digunakan Malmquist Productivity Index (MPI) sebagai alat ukur tingkat produktivitas. Temuan penelitian didapati bahwa produktivitas Bank Umum Konvensional sedikit lebih unggul dibanding Bank Umum Syariah dengan kontribusi dari Technical / Technological Change (TECHCH) menjadi komponen penyusun TFPCH yang paling berpengaruh terhadap indeks TFPCH. Selama periode penelitian juga ditemukan indikasi Technical increase pada kedua jenis bank. Hasil penelitian ini memberi implikasi kepada pelaku industri perbankan untuk meningkat efisiensi khususnya dari segi pemanfaatan teknologi dalam mendukung efisiensi pelayananan kepada nasabah.
\end{abstract}

Kata kunci: kinerja; total factor productivity index; malmquist productivity index; bank Syariah dan bank konvensional.

\title{
INTRODUCTION
}

Over the past few decades, Islamic banks have played an important role as a new alternative to the banking industry. According to the Financial Services Authority (2015), in 2014 Indonesia was ranked 9th in the world in Islamic financial assets. This is a significant development for Islamic banks in Indonesia where the operational systems of Islamic banks are very different from conventional banks and must compete in improving banking performance. Alexakis et al. (2019) mentioned a significant difference between Islamic and Conventional Banks that Islamic Banks prioritizing Sharia principles in terms of prohibiting usury do not use money as a commodity, and transactions based on justice and prohibit uncertainty (gharar). Bahrini (2015) argued that Islamic banks operate according to the rules and principles of Sharia that regulate the religious practices, daily life and economic activities of a Muslim.

The Islamic banking industry is increasingly developing into a financial model that can continue to run and the number is growing very rapidly (Ariss, 2010). Mansoor \& Ishaq (2008) argued that Islamic banking and the Islamic financial system are becoming increasingly popular because they offer more civilized alternatives than conventional financial systems.

In Indonesia, the bank is considered as one of the economic drivers. In 1983, the Government of Indonesia undertook deregulation, to provide flexibility to banks in setting interest rates, to create an efficient bank condition. The development of the Islamic financial economy began in 1992 with the establishment of the first Islamic bank, Bank Muamalat Indonesia. Currently, based on Islamic banking statistics published by the Financial Services Authority (2019) as of January 2019 there are at least 14 Islamic Banks, 20 Islamic Business Units, and 165 Islamic Rural Banks.

Though the interest in the Islamic banking sector is growing, several studies show that the Islamic banking industry is still less efficient compared to conventional banks in various countries. It is empirically related to the performance 
Marhanum Che Mohd Salleh, Lina Nugraha Rani: Productivity $\mid 71$ Comparation of Islamic and Conventional Banks in Indonesia

of Islamic banks that are still in development (Beck et al., 2013; Ariss, 2010). Currently, the competition between conventional and Islamic banks is not at a significant level, but Islamic banks have their place in society. Therefore, studies on the level of productivity of the Islamic banking sector have become an important part of the banking literature. Besides an analysis of productivity shifting in the banking sector should also be concerned with bankers and policymakers. An increase in productivity is expected as a good signal of performance improvement in the ability of banks to efficiently manage their resources, reduce prices, and improve the quality of services (Bahrini, 2015).

Berger \& Mester (2003) revealed the response of changes in the structure of the financial services industry and advances in financial and non-financial technology is evidenced by the considerable interest in the study of bank productivity. Furthermore, Koutsomanoli-Filippaki et al., (2009) added that the increase in productivity is expected to make a better bank performance, competitive prices, improved quality of services, and increased allocation of resources.

Discussions about productivity in a particular company involve the effective use and integration of available resources. This stage is needed in the company's growth and development process and internalization of various sub-system improvements within the company. According to Diaz-Chao et al., (2015) productivity refers to the optimal use of company resources to achieve effective and efficient targets within the agreed value framework.

Abbas et al., (2015) explained the Malmquist Index is a unique measure of productivity and allows researchers to decompose the index of productivity change into components so that the index results will raise reasons for any growth or decline in productivity. Abbas et al., (2015) added that this method is a comprehensive tool for analyzing the performance of a sector that involves many inputs and outputs in its operational activities. As we know in producing various services and products, banking will use a lot of inputs in it.

Data Envelopment Analysis (DEA) shows the service unit inefficiency specifications (Charnes, et al., 1978). Many researchers acknowledge that this method is relatively easy to use as an operational modeling process for performance evaluation. Malmquist Productivity Index (MPI) is a productivity measurement method based on Data Envelopment Analysis (DEA). Caves, Christensen, and Diewert (CCD) introduced the Malmquist Productivity Index (MPI) in 1982. Then followed by Fare, Grosskopf, Lindgren, and Roos in 1992 and Fare, Grosskopf, Norris, and Zhang in 1994 which implemented the Malmquist Productivity Index MPI) empirically (Kamarudin et al., 2017).

This study used the Malmquist Productivity Index (MPI) based on Data Envelopment Analysis (DEA) to measure and compare the performance of Islamic and conventional banks in Indonesia. The sample of this research was the Islamic Bank and Conventional Bank, which became the parent of the establishment of the Islamic Bank, from 2011 to 2018.

Ariss (2010) described that Islamic banks and conventional banks have tight competition in the world level and have an impact on the resilience level of the country's financial stability. Thus, this study focused on the comparison between Islamic and Conventional Bank productivity. The result of the Malmquist 
Productivity Index (MPI) is expected to illustrate the comparison of the productivity levels of Islamic and Conventional Banks in Indonesia. Furthermore, it also describes components of changes in productivity from the level of efficiency and technology used based on predetermined inputs and outputs (Bahrini, 2015).

In recent years, many works of literature use the Malmquist Index as a measure of productivity changes (Grifell-Tatjĕ \& Lovell: 1995). The nonparametric Malmquist Productivity Index is often used to assess overall productivity change in companies in various industries (Simar \& Wilson: 2019). Multifactor or better known as Total Factor Productivity (TFP) measures the account by the use of several input factors in production and is therefore considered more suitable for measuring performance and comparisons between companies over time.

Efficiency and productivity are concepts that show the ratio of the results of a comparison between input and output. The ratio shows that efficiency and productivity can be controlled by manipulating input and output management, or both at the same time.

Total Factor Productivity (TFP) is used to measure the relationship between outputs and inputs together. The relationship is expressed in the ratio of the output index to the aggregate input index. If the ratio increases, more output can be produced using a certain number of inputs, or several outputs can be produced using fewer inputs (Coelli et al., 2005).

Changes in total factor productivity (TFPCH) describe changes in the production process as a result of changes in terms of quantity of inputs, quality of production factors, and capacity utilization. Malmquist Productivity Index (MPI) is a method of measuring productivity levels based on Data Envelopment Analysis (DEA). Earlier Fisher's Index (1922) and Tornqvist (1936) were used to evaluate technological changes until (1953) Malmquist put forward the idea of a price compensation index. It introduced and developed by Caves, Christensen, and Diewert (CCD) in 1982 as a tool to measure productivity growth over time (Choudhury et al., 2015).

The Malmquist Productivity Index is a bilateral index to compare the production technologies of two economic elements (Cooper et al., 1999). The Malmquist Productivity Index is based on the concept of a production function that measures the maximum production function within the specified input limits. In its calculation, this index consists of several results, efficiency change, technological change, pure efficiency change, economic scale change, and TFP change.

Several previous studies that measure banking productivity through TFPCH values include Yaumidin (2007), Norma, et al., (2010), Choudhury, M. Aet al., (2015), Raéf Bahrini (2015), Kamarudin, Fet al., (2017), Alexakis et al. (2019), Mansour and El Moussawi (2019). Yaumidin (2007) compares the efficiency of Islamic banks in the Middle East and Southeast Asia. The study was based on bank failures that were influenced by financial crisis factors both domestically and internationally. As a result, Islamic banks in Southeast Asia were slightly more efficient than Islamic banks in the Middle East. The tragedy of 9/11 in 2001 and the Iraq war in 2002 was allegedly the cause. Likewise with the TFPCH value. 
Marhanum Che Mohd Salleh, Lina Nugraha Rani: Productivity 73 Comparation of Islamic and Conventional Banks in Indonesia

Norma et al., (2010) examined the efficiency of conventional and Islamic unit trust companies in Malaysia during 2002-2005. In its research findings, Islamic bank units obtain TFP values above the average. During the analysis period, it was also found that Malaysian unit trust companies experienced a TFP setback and the main factor was caused by a decrease in technical efficiency. However, changes in efficiency contribute positively to TFP. Pure efficiency is the biggest component contributing to changes in efficiency compared to the scale of efficiency.

Choudhury et al., (2015) evaluated changes in productivity in the banking sector and compared the performance of Islamic and conventional banks during 2005-2009. The results showed the level of productivity for Islamic and conventional banks had decreased. The Pakistani banking sector was facing a decline as a result of the crisis after 2007. However, the Pakistani banking sector can still minimize damage and controlled the situation. Islamic bank productivity growth was better than conventional banks, but the differences were not statistically significant.

Bahrini (2015) conducted a study of the level of productivity and determinants of Islamic banking with cross-country data of 33 banks operating in 10 MENA countries. Bahrini's (2015) showed that the productivity of the Islamic bank MENA experienced a slight average growth during 2006-2011. The decline in productivity of the Islamic bank MENA occurred during the period of the global financial crisis. Islamic banks from GCC experienced a decline between 2006 and 2011. The main problem of these banks was because they cannot compensate for the technical setbacks by increasing efficiency. Efficient banks during the study period were mostly small. The main factors influencing the productivity growth of MENA Islamic banks were capital adequacy, size, management quality, diversification, profitability, and liquidity.

Kamarudin et al., (2017) examined operational productivity and potential determinants that influence Islamic banks in Southeast Asian countries, especially in Brunei, Indonesia, and Indonesia during 2006-2014. The sample used was 17 banks operating in Malaysia, 11 banks in Indonesia, and 1 bank in Brunei. Then the banks are grouped into 23 domestic ownership banks and 6 foreign ownership banks. It found that both types of bank ownership showed progress in TFPCH related to an increase in EFFCH. Foreign banks were slightly more productive than domestic banks due to efficiency increasing. However, there was no statistically significant difference between the efficiency and productivity of foreign and domestic Islamic banks. Other findings also proved that capitalization, liquidity, and world crisis economy are determinants of the potential productivity of Islamic banks operating in all three countries during the study period.

Alexakis, et al. (2019) conducted a comparative study of the performance and productivity of Islamic banks with conventional banks during the 2006-2012 crisis periods in 6 GCC (Gulf Cooperation Council) countries. The results showed that based on the MPI frontier Meta values showed that technology in conventional banks led to financial crises and decreased productivity. Instead, Islamic banks show that the technical component of efficiency and technology in the value of the MPI showed heterogeneity in the Islamic bank group. The result suggested regulators use various policies on the group of Islamic banks. 
Mansour \& Moussawi (2019) measure banks' productivity in 12 Arab countries. The result of the study indicated that technical progress has an important responsibility for increasing banking productivity in Arabs compared to technical efficiency. It also suggested that policymakers and banking managers determine further practical steps in improving technical efficiency so that profits in technology improvement can also be obtained.

Chen et al. (2019), developed productivity measurements not only from the value of the Malmquist Productivity Index (MPI) but also supplemented by the Metafrontier Luenberger Productivity Indicator (LP) at 50 banks in Taiwan and China. The result showed that during the 2010-2014 banking productivity in Taiwan and China have decreased productivity. There was interesting empirical evidence found that banks in Taiwan and China have high levels of efficient earnings and high allocation efficiency in the meta technology used while allocation efficiency is the main factor causing earnings to be inefficient. It also suggested mutually beneficial cooperation between Taiwan and China banks, because China has better technology than Taiwan, to increase banking productivity in both countries.

The development of Islamic banking needs to be supported by a productivity analysis to measure output growth in the banking industry sector. Productivity in this study is a measurement with Total Factor Productivity (TFP) by not partially differentiating factors of production. Total Factor Productivity (TFP) itself is considered important because it is a measure of productivity that takes into account all relevant factors of production.

Besides, the literature that discusses banking productivity in developing countries is also still lacking. This gap also initiates further research on how to compare the productivity performance of Islamic banking and conventional banking, especially in developing countries like Indonesia.

\section{RESEARCH METHODS}

This study uses a quantitative method to estimate changes in total factor productivity (TFPCH) and its components using the MPI, which was measured by DEAP 2.1 (Coelli, 1996). Banking productivity was measured using the MPI used in the research of Alexakis et al. (2019), by using several outputs and inputs to measure technical efficiency and at the same time being able to measure changes in productivity.

Alexakis et al. (2019) state that the value on the MPI shows an increase in productivity between $\mathrm{t}$ and $\mathrm{t}-1$ unless the MPI value is less than 1 will show the opposite result or decrease in productivity. MPI has two components as follows:

Technical Efficiency Change from period $t$ to $t+1$ TECt, $t+1^{*}$, shows that all DMUs are nearing production frontiers all the time. If the value is greater or less then it needs improvement either increase or decrease. This component measures the efficiency of bank resource use by looking at its specifically assessed impacts as being appropriate for bank indicators to make improvements.

Technology Change from period $t$ to $t+1$ TECt, $t+1 *$, shows that the production frontiers have shifted over time. If the value is greater or less, it will require improvement in both the increase or decrease in technology. The idea of 
Marhanum Che Mohd Salleh, Lina Nugraha Rani: Productivity $\mid 75$ Comparation of Islamic and Conventional Banks in Indonesia

improvement in the form of new technology must be used by banks in the form of financial products that enable banks to achieve high productivity. In other words, this component is an indicator of bank management to innovate so that banks can expand their products practically even though competitors are also doing the same thing.

The input-output approach in Malmquist is the maximum number of factors that we can explain by using inputs as a specific period and by maintaining a constant level of production in the measurement period (Mansour \& Moussawi, 2019). Productivity measurement with Malmquist can be measured using both parametric and non-parametric methods through DEA (Data Envelopment Analysis). Malmquist index is widely used in several banks by using three components, namely Technical Change, Technical Efficiency Change and Scale Efficiency (Duygun et al, 2016). According to Bitar et al. (2019), DEA is an effective method in determining efficiency through the measurement of inputs and outputs.

An approach of the bank as an intermediary is used in which the banking institution functions as an intermediary for channeling funds for investors and fund collectors in the form of deposits from depositors. The intermediation approach is a very appropriate approach to describe the function of banking institutions (Ascarya et al, 2009). The output orientation approach is used with the assumption that the bank always wants an increase in output with a fixed number of inputs. Besides, an orientation approach is more suitable for research in developing countries (Kamarudin et al., 2017).

\section{Data and Variable}

Samples for this study is 7 Islamic Banks and 7 Conventional Banks of 2011-2018. Referring to the research of Raéf Bahrini (2015), the approach for input and output variables of banks in this study used an intermediation approach. The input variable consisted of Total Fixed Assets (X1), Labor Costs (X2), and Third-Party Funds (X3). The output variable consisted of Financing (Y1), Total Operating Income (Y2), and Portfolio Investment (Y3). Bank input and output variable data were obtained from annual financial reports, the balance sheet and income statement published both on the website of each bank sample and from Bank Indonesia. The sample descriptions used in this study are described in appendix 1.

\section{RESULTS AND DISCUSSION}

This study examined the productivity performance of Islamic Banks and Conventional Banks. The measurement of productivity level carried out by looking at the Total Factor Productivity Change (TFPCH) index through the MPI method that also produced three TFPCH forming component variables, Technical / Technological Change (TECHCH), Technical Efficiency Change (EFFCH), and Scale of Efficiency Change (SECH). A positive EFFCH (positive efficiency change) indicates that efficiency changes are approaching the border. While positive TECHCH (positive technological change) shows that there is a technological change or innovation. Fare et al., (1994) explains Technical Efficiency Change (EFFCH) is broken down into two components, namely Pure 
Technical Efficiency Change (PECH) and Scale of Efficiency Change (SECH). The results of MPI observation in all banks are shown in Table 1.

Based on the geometric average of the Malmquist index, in Table 1 it can be seen that during 2011-2018 there was a productivity growth in all banks both Islamic and Conventional Banks as indicated by the TFPCH value of 1,074 or an increase of +7.4 percent. TFPCH growth was caused by the growth of TECHCH, in which there was an average technical increase of 1,098 (+ 9.8 percent)

Table 1. MPI Observation Result of All Banks

\begin{tabular}{lccccc}
\hline \multicolumn{1}{c}{ Year } & EFFCH & TECHCH & PECH & SECH & TFPCH \\
\hline $2011-2012$ & 0.943 & 0.985 & 0.951 & 0.992 & 0.929 \\
$2012-2013$ & 0.986 & 0.982 & 1.032 & 0.955 & 0.968 \\
$2013-2014$ & 1.066 & 0.796 & 1.023 & 1.042 & 0.849 \\
$2014-2015$ & 0.966 & 1.025 & 0.985 & 1.010 & 1.021 \\
$2015-2016$ & 1.010 & 1.176 & 1.016 & 0.994 & 1.188 \\
$2016-2017$ & 0.963 & 0.978 & 0.993 & 0.970 & 0.942 \\
$2017-2018$ & 0.891 & 2.117 & 0.997 & 0.893 & 1.886 \\
\hline Mean & $\mathbf{0 . 9 7 8}$ & $\mathbf{1 . 0 9 8}$ & $\mathbf{0 . 9 9 9}$ & $\mathbf{0 . 9 7 9}$ & $\mathbf{1 . 0 7 4}$ \\
\hline
\end{tabular}

Islamic and Conventional Banks make technological updates or innovations in their business. The banking industry in Indonesia has made use of technological advancements as an effort to improve the production process. Innovations in technology have proven to be successful in increasing productivity in both banks.

Table 1 showed that Islamic and Conventional Banks experienced a decrease in efficiency during 2011-2018. The EFFCH index value of $<1$ indicated that the performance of both types of banks was less efficient in terms of efficiency changes. The SECH component was the biggest contributor to the decline in the EFFCH performance with an annual average of 0.979 (-2.1 percent). In other words, banks in Indonesia experienced a decline in the scale of company operations. They failed to achieve efficient economies of scale during the production process. In contrast, the PECH showed a slightly higher value than the value of SECH even though it had not reached a truly efficient condition yet.

Table 2. Observation Result of Islamic Bank MPI

\begin{tabular}{lccccc}
\hline \multicolumn{1}{c}{ Year } & EFFCH & TECHCH & PECH & SECH & TFPCH \\
\hline $2011-2012$ & 0.988 & 1.006 & 1.000 & 0.988 & 0.995 \\
$2012-2013$ & 0.950 & 1.207 & 0.976 & 0.973 & 1.147 \\
$2013-2014$ & 1.074 & 0.759 & 1.024 & 1.049 & 0.815 \\
$2014-2015$ & 0.990 & 1.176 & 1.000 & 0.990 & 1.163 \\
$2015-2016$ & 0.980 & 1.244 & 1.000 & 0.980 & 1.219 \\
$2016-2017$ & 1.003 & 1.043 & 1.000 & 1.003 & 1.046 \\
$2017-2018$ & 1.017 & 0.977 & 1.000 & 1.017 & 0.994 \\
\hline Mean & $\mathbf{1 . 0 0 0}$ & $\mathbf{1 . 0 4 6}$ & $\mathbf{1 . 0 0 0}$ & $\mathbf{1 . 0 0 0}$ & $\mathbf{1 . 0 4 6}$ \\
\hline
\end{tabular}

The TFPCH value of Conventional Banks was also more varied compared to the Islamic Banks which tend to be more stagnant. In table 2 the index value of the Islamic Banks showed a technical increase of 1,046 (+4.6 percent), and the 
Marhanum Che Mohd Salleh, Lina Nugraha Rani: Productivity $\mid 77$ Comparation of Islamic and Conventional Banks in Indonesia

TECHCH component contributed to improving productivity. This shows that in its operations the Islamic Bank has sought to involve technological developments in the production process to respond to the changing times. Besides, the EFFCH showed efficient conditions with an index value of 1 . The results of the measurements of Islamic bank productivity in Indonesia in Table 2 show a slight increase in productivity during the study period 2011-2018, in line with Bahrini (2015), where a slight increase in productivity is the impact of the global financial crisis (2007-2008).

In table 2, PECH and SECH also had an index value of 1 . This value indicated that there was no change or growth of efficiency. This means that throughout the study period, Islamic Banks in Indonesia has reached the most technically efficient conditions both in the previous year, at present, and in the following year.

Table 3. Observation Result of Conventional Banks MPI

\begin{tabular}{lccccc}
\hline \multicolumn{1}{c}{ Year } & EFFCH & TECHCH & PECH & SECH & TFPCH \\
\hline $2011-2012$ & 1.009 & 0.814 & 0.988 & 1.021 & 0.821 \\
$2012-2013$ & 0.979 & 1.107 & 1.011 & 0.969 & 1.084 \\
$2013-2014$ & 1.035 & 0.692 & 1.001 & 1.034 & 0.716 \\
$2014-2015$ & 0.992 & 1.075 & 0.992 & 1.000 & 1.066 \\
$2015-2016$ & 1.009 & 1.106 & 1.008 & 1.000 & 1.115 \\
$2016-2017$ & 0.962 & 1.034 & 0.979 & 0.982 & 0.995 \\
$2017-2018$ & 1.040 & 1.819 & 1.021 & 1.018 & 1.891 \\
\hline Mean & $\mathbf{1 . 0 0 3}$ & $\mathbf{1 . 0 4 9}$ & $\mathbf{1 . 0 0 0}$ & $\mathbf{1 . 0 0 3}$ & $\mathbf{1 . 0 5 2}$ \\
\hline
\end{tabular}

In table 3, there was productivity growth in Conventional Banks as indicated by the TFPCH value of $1,052(+5.2$ percent) annual average. Similar to what happened at Islamic Banks, the TECHCH component also contributed to improving productivity performance at Conventional Banks with an index value of 1,049 (+ 4.9 percent). This figure showed a slight difference (3 percent) between Conventional Banks and Islamic Banks. The application of new technological innovations in the process of delivering quality products and towards the direction of technological change that is more sophisticated and modern has proven to be successful in making Conventional Banks slightly superior to their competitors. The EFFCH showed an index value of 1,003 (+3 percent), meaning that Conventional Banks are more efficient in the use of existing technology during the entire research period.

The SECH become the largest value, which means that all samples of Conventional Banks in the study period have been able to manage and utilize the inputs used during the production process so that they can produce maximum-value output. Although the value is not classified as high, at least this shows that Conventional Banks are slightly superior to Islamic banks. This is in line with the results of Abbas et al. (2015) research illustrating that conventional bank productivity results are higher than Islamic banks, then relying on enhancing 
customer-safe and reliable technology, verifying banking services and products, adding branch offices to serve all of its customers.

Based on the values in tables 2 and 3 the TFPCH growth of Conventional Banks was higher than Islamic Banks during 2011-2018. Both types of banks had experienced productivity growth with a difference of 6 percent annually on average.

Furthermore, for the PECH values in table 2 and table 3, it appeared that the performance between Islamic and Conventional Banks during 2011-2018 showed an increase in productivity. It means the bank has reached the most technically condition and technically efficient.

\section{Productivity Comparation of Islamic and Conventional Banks in Indonesia}

Thus, according to the results that have been processed by the MPI method, Islamic and Conventional Banks prove that innovation in technology has a positive impact on company performance, especially on productivity. It is expected that both types of banks will be able to continue to pay attention to technological developments to produce quality output and improve banking services in the form of attractive financial products for customers. Bank managers must continue to innovate and strive to meet the demands of consumers who are always experiencing developments following technological changes.

Based on table 2 and table 3 , the MPI value of Islamic and Conventional Banks did not have much difference. Although Islamic Banks having a level of productivity that almost the same as conventional ones, Islamic banking regulators must obtain special regulations that are different from conventional banks. Since the basic principles of Islamic Banks are very different from the conventional ones (Alexakis et al., 2019). As for the managers of both banks, to reduce operational costs, they must develop and use financial technology. However, in the process of developing financial technology products, Islamic Banks must continue to receive supervision and approval from the Islamic Supervisory Board (DPS) to maintain operational purity under Sharia.

Kamarudin et al., (2017), analysed the technological advancement of Islamic banks compared to conventional banks is still relatively behind. Islamic banks could introduce more comprehensive Internet banking services, mobile applications, or even more convenient services by increasing the unit numbers and functionality of Automated Teller Machines (ATMs).

\section{CONCLUSION}

This study examined and compared the level of productivity of the banking sector in Indonesia during 2011-2018. Productivity analysis used the MPI which raised an index consisting of several results, TFP change with the constituent components of efficiency change, technological change, pure efficiency change, economic scale change. However, the analysis only involved technological change and efficiency change. While pure efficiency change and economic scale change were the components of efficiency change.

The results found that the banking sector in Indonesia experienced productivity growth. It showed from the results of TFPCH with the MPI index value. Both types of banks experienced productivity growth with a difference of 
Marhanum Che Mohd Salleh, Lina Nugraha Rani: Productivity 79 Comparation of Islamic and Conventional Banks in Indonesia

percentage of the annual average. Other findings also found that the TECHCH component contributed to the increased productivity of Islamic Banks and Conventional Banks. Furthermore, both types of banks were also in a technically efficient condition. In general, the productivity performance of Conventional Banks was slightly superior compared to Islamic Banks. But it did not rule out the possibility that Islamic Banks will be better than Conventional Banks in the future. Islamic Banks were expected to continuously improve the organizational structure, managerial aspects, services, and efficiency in the production process to face competition in the banking world.

Furthermore, from the above findings, it is concluded that the step of technological reform will have a good impact on the sustainability of company performance. It is recommended for banking practitioners to provide special allocations in the field of technology to produce quality outputs and improve banking services, such as smart contracts (online contracts) or banking agreements in every online transaction. The technology currently plays an important role in all lines of people's daily lives. Many sectors have carried out digitalization reforms to respond to the transformation.

The MPI values in all banks, both Islamic and conventional banks, during the study period showed an increase in productivity. The increase of productivity, reflected by the increase of the TFPCH value, due to an increase in technology $(\mathrm{TECH})$, where both the TFPCH and the TECH components have a value of more than 1. This implies that policymakers and banking managers must continue improving the technology to increase the efficiency and the company profit has an important role for customer trust and the sustainability of the company itself.

\section{REFERENCES}

Abbas, M., Hammad, R. S., Elshahat, M. F., \& Azid, T. (2015). Efficiency, productivity and Islamic banks: an application of DEA and Malmquist index. Humanomics. https://doi.org/10.1108/H-03-2013-0022

Alexakis, C., Izzeldin, M., Johnes, J., \& Pappas, V. (2019). Performance and productivity in Islamic and conventional banks: Evidence from the global financial crisis. Economic Modelling, 79, 1-14. https://doi.org/10.1016/j.econmod.2018.09.030

Ariss, R. T. (2010). Competitive conditions in Islamic and conventional banking: A global perspective. Review of Financial Economics, 19 (3), 101-108. https://doi.org/10.1016/j.rfe.2010.03.002

Ascarya, Diana, Yumanita, \& Guruh, S. R. (2009). Analisis Efisiensi Perbankan Konvensional dan Perbankan Syariah di Indonesia dengan Data Envelopment Analysis (DEA). Current Issues Lembaga Keuangan Syariah. Prenada Media Group, 1-34.

Bahrini, R. (2015). Productivity of MENA Islamic banks: a bootstrapped Malmquist index approach. International Journal of Islamic and Middle Eastern Finance and Management, 8(4), 508-528. https://doi.org/10.1108/IMEFM-11-2 
Beck, T., Demirguc-Kunt, A., \& Merrouche, O. (2013). Islamic vs. Conventional banking: Business model, efficiency and stability. Journal of Banking \& finance, 37 (2), 433-447. https://doi.org/10.1016/j.jbankfin.2012.09.016

Berger, A. N., \& Mester, L. J. (2003). Explaining the dramatic changes in performance of US banks: technological change, deregulation, and dynamic changes in competition. Journal of financial intermediation, 12(1), 57-95. https://doi.org/10.1016/S1042-9573(02)00006-2

Bitar, M., Pukthuanthong, K., \& Walker, T. (2019). Efficiency in Islamic vs. conventional banking: The role of capital and liquidity. Global Finance Journal, 100487. https://doi.org/10.1016/j.gfj.2019.100487

Caves, D.W., Christensen, L.R. and Diewert, W.E. (1982), "The Economic Theory of Index Numbers and The Measurment of Input, Output, And Productivity", Econometrica, Vol. 50, pp. 1393-1414. https://www.jstor.org/stable/1913388

Charnes, A., Cooper, W.W. and Rhodes, E. (1978). Measuring the efficiency of decision making units. European Journal of Operations Research 2 (6): 42944. https://doi.org/10.1016/0377-2217(78)90138-8

Chen, X., Fu, T.-T., Juo, J.-C., \& Yu, M.-M. (2019). A comparative analysis of profit inefficiency and productivity convergence between Taiwanese and Chinese banks. BRQ Business Research Quarterly. https://doi.org/10.1016/j.brq.2019.02.001

Coelli, T.J. 1996, A Guide to DEAP Version 2.1: A Data Envelopment Analysis Program, CEPA Working Paper 96/08.

Coelli, T.J., Rao, D.S.P., O'Donnell, C.J, and Battese, G.E. (2005), An Introduction to Efficiency and Productivity Analysis, Springer Science and Business Media, New York, NY.

Diaz-Chao, Á., Sainz-González, J., \& Torrent-Sellens, J. (2015). ICT, innovation, and firm productivity: New evidence from small local firms. Journal of Business Research, 68(7), 1439-1444. https://doi.org/10.1016/j.jbusres.2015.01.030

Duygun, M., Sena, V., \& Shaban, M. (2016). Trademarking activities and total factor productivity: Some evidence for British banks using a metafrontier approach. Journal of Banking \& Finance, 72, S70-S80. https://doi.org/10.1016/j.jbankfin.2016.04.017

Fare, R., S. Grosskopf, B. Lindgren and P. Roos, (1994), Productivity Developments in Swedish Hospital: A Malmquist Output Index Approach, in A. Charnes, W.W. Cooper, A. Lewin and L. Seiford (eds.), Data Envelopment Analysis: Theory, Methodology and Applications, Boston: Kluwer Academic Publishers. https://doi.org/10.1007/978-94-011-0637-5_13

Fisher, I. (1922), The Making of Index Numbers, Hoghton-Muflin, Boston, MA.

Grifell-Tatjé, E., \& Lovell, C. K. (1995). A note on the Malmquist productivity index. Economics letters, 47(2), 169-175. https://doi.org/10.1016/01651765(94)00497-P

Kamarudin, F., Hue, C. Z., Sufian, F., \& Mohamad Anwar, N. A. (2017). Does productivity of Islamic banks endure progress or regress? Empirical evidence using data envelopment analysis based Malmquist Productivity Index. Humanomics, 33(1), 84-118. https://doi.org/10.1108/H-08-2016-0059 
Koutsomanoli-Filippaki, A., Margaritis, D., \& Staikouras, C. (2009). Efficiency and productivity growth in the banking industry of Central and Eastern Europe. Journal of Banking \& Finance, 33(3), 557-567. https://doi.org/10.1016/j.jbankfin.2008.09.009

Mansoor Khan, M., \& Ishaq Bhatti, M. (2008). Islamic banking and finance: On its way to globalization. Managerial Finance, 34 (10), 708-725. https://doi.org/10.1108/03074350810891029

Mansour, R., \& El Moussawi, C. (2019). Efficiency, technical progress and productivity of Arab banks: A non-parametric approach. The Quarterly Review of Economics and Finance. https://doi.org/10.1016/j.qref.2019.02.002

Norma, Saad, M., Shabri Abd. Majid, M., Kassim, S., Hamid, Z., \& Yusof, R. M. (2010). A comparative analysis of the performance of conventional and Islamic unit trust companies in Malaysia. International Journal of Managerial Finance, 6(1), 24-47. https://doi.org/10.1108/17439131011015779

Otoritas Jasa Keuangan. (2015). Road Map of Indonesian Islamic Banking 2015 2019. OJK International Conference on Islamic Finance

Otoritas Jasa Keuangan. 2019. Statistik Perbankan Syariah. Jakarta: Otoritas Jasa Keuangan.

Simar, L., \& Wilson, P. W. (2019). Central limit theorems and inference for sources of productivity change measured by nonparametric Malmquist indices. European Journal of Operational Research, 277(2), 756-769. https://doi.org/10.1016/j.ejor.2019.02.040

Tornqvist, L. (1936), “The Bank of Finland's Consumption Price Index”, Bank of Finland Monthly Bulletin, Vol. 10, pp. 1-8.

Yaumidin, U.K. 2007, Efficiency in Islamic banking, A non-parametric approach, Buletin Eko 
82 Al-Uqud: Journal of Islamic Economics

Volume 4 Issue 1, January 2020

Appendix 1. Descriptive Statistic Input-Output Variable

\begin{tabular}{lcccccc}
\hline Description & $\begin{array}{c}\text { Total Fixed } \\
\text { Assets (X1) }\end{array}$ & $\begin{array}{c}\text { Labor Cost } \\
\text { (X2) }\end{array}$ & $\begin{array}{c}\text { Third-party } \\
\text { fund (X3) }\end{array}$ & $\begin{array}{c}\text { Financing } \\
\text { (Y1) }\end{array}$ & $\begin{array}{c}\text { Total } \\
\text { Operating } \\
\text { Income (Y2) }\end{array}$ & $\begin{array}{c}\text { Portfolio } \\
\text { Investment } \\
(\text { Y3) }\end{array}$ \\
\hline $\begin{array}{l}\text { Mean } \\
(2011-2018)\end{array}$ & 4618949.384 & 3524629.759 & 164851166.3 & 134787206.5 & 7513812.518 & 26024003.08 \\
\hline $\begin{array}{l}\text { St. Dev } \\
(2011-2018)\end{array}$ & 8285820.216 & 5146822.526 & 252395337.7 & 212266378.1 & 12688257.36 & 39310795.28 \\
\hline
\end{tabular}

Copyright (C) 2020, Al-Uqud: Journal of Islamic Economics

http://journal.unesa.ac.id/index.php/jie 